\author{
V.S. Pidgorskyi, N.K. Kovalenko, I.L. Garmasheva
}

Zabolotny Institute of Microbiology and Virology, NAS of Ukraine, 154 Zabolotny St., Kyiv, 03143, Ukraine

\title{
TAXONOMIC RESEARCH, BIOLOGICAL PROPERTIES AND BIOSYNTHETIC ACTIVITY OF LACTIC ACID BACTERIA AND BIFIDOBACTERIA ISOLATED FROM VARIOUS NATURAL ECOLOGICAL NICHES
}

Lactic acid bacteria (LAB) and bifidobacteria play an important role in human health and have wide application in food industry. LAB propagation and high quantity of them in natural substrates testifies that many species of these microorganisms have adapted to the environmental conditions, and specific ecological niches. Lactic acid bacteria isolated from different ecological niches were identified using phenotypic and molecular-genetic methods. The species of Lactobacillus plantarum, Enterococcus faecium, E. durans, E. hirae, E. faecalis were identified among LAB. Bifidobacteria were majorly represented by Bifidobacterium infantis, $B$. breve, $B$. animalis, B. bifidum and $B$. dentium species. The intraspecific heterogeneity of $L A B$ and bifidobacteria strains isolated from distal part of intestinal tract of people belonging to various age group was investigated. The role of teichoic acids in adhesion of the studied LAB strains to human's buccal epithelium was evaluated. Different biological activities, such as gastric juice resistance, tolerance to bile acids, adhesive properties to macroorganism's epithelial cells, sensitivity to clinically significant antibiotics were studied. All of these properties make specific LAB and bifidobacteria strains to be promising for probiotics and functional foods creation.

K e y wo rds: lactic acid bacteria, bifidobacteria, probiotic properties, taxonomy.

Lactic acid bacteria (LAB) propagation and high quantity of them in natural substrates testifies that many species of these microorganisms have adapted to the environmental conditions, and specific ecological niches are LAB's native habitats. These issues are widely covered in the literature. However, for example, traditionally it was considered that bifidobacteria along with certain species of lactic acid bacteria present the microbiota of newborn children and infants [32]. In the meantime, the data obtained in the last several years testifies that lactic acid bacteria and bifidobacteria exist copiously in the alimentary tract of people of various age groups, especially among long-living persons [23, 31]. Furthermore, lactic acid bacteria and bifidobacteria inhabit the alimentary tract of farm livestock, insects, dolphins [33], plants' surfaces [39], etc.

Over the last years these groups of microorganisms attract special attention of researches all over the world. It is mainly caused by their positive effects on human health being used as components of probiotics and functional foods $[4,12,19,21]$.

In compliance with WHO's requirements probiotic microbial strains shall precisely match with the species name adopted by modern international list of microorganisms [24]. However, it is worth mentioning, that the determination of LAB's systematic position along with certain representatives 
of Bifidobacterium genus is quite often a matter of argument. On the one hand, it is due to the live environment effect on these bacteria's physiology and, on the other hand, while adapting to certain conditions of ecological niches these microorganisms can modify some morphology-cultural characteristics and consequentially manifest heterogeneous properties, causing inaccuracy of species classification with microbiological methods [41,9]. The use of API 20 Strep and API 50CHL test systems testified incorrectness of identification of closely related enterococci species and lactobacilli conducted based only on biochemical tests $[2,16,18]$. In the result, a demand arose for sensitive and fast methods of species-related identification of strains, isolated from ecological niches, as their species diversity is much more wide then can be determined with test-systems and existing schemes of traditional identification. Moreover the necessity for simultaneous use of several molecular-genetic methods became essential $[1,9]$.

Considering the fact that for the last years we have collected vast number of lactobacilli, enterococci, bifidobacteria and other LAB species' strains, isolated from various ecological niches, the necessity arose to use polyphase taxonomic principles while identifying the species. These principles include microbiologic, chemotaxonomic and various molecular-genetic methods [14, $23,39]$. Achievement of exact identification made it possible to perform strains screening to use them as components of probiotics and functional food.

In such a way our research has been first and foremost focused on the study of phenotypic characteristics of the wide range of LAB and bifidobacteria strains using microbiological methods. The performance of species identification for these groups of microorganisms tended to be insufficient due to the manifestation of heterogenic properties among some species of lactic acid bacteria, enterococci and bifidobacteria. Moreover while comparing the results obtained with classic methods with API-testing results we've quite often observed gaps in certain properties $[9,25]$.

According to data received along with microbiological methods of LAB identification we've investigated chemotaxonomic features, in particular fatty acids profile of cellular lipids. Literature concerning the issue is insufficient [35], however in the recent years due to taxonomic methods improvement many researches have focused their attention on fatty acids profile of lactic acid bacteria, enterococci cellular lipids as differential species character when describing type strains [5, 7, 36-38].

Application of the method of combined gas chromatography and mass spectrometry made it possible to identify fatty acids of C14-C19 carbonic chain length (saturated - tetradecanoic (C14:0), pentadecanoic (C15:0), hexadecanoic $(\mathrm{C} 16: 0)$ and octadecanoic $(\mathrm{C} 18: 0)$, unsaturated - hexadecenoic $(\mathrm{C} 16: 1)$ and octadecenoic (cis and trans isomers C18:1), and also cyclopropanoic acid (C19:0cyc)) in the strains of enterococci subject to investigation. These acids have been identified in all Enterococcus species (Tabl), however, their presence was not species-specific. The only exception was the pentadecanoic acid absent in Enterococcus faecalis strains. This was proved with the analysis of similarity of the studied strains with regards to their quantitative and qualitative fatty acid content profile. We've used cluster analysis and built Enterococcus strains similarity dendrogram based on the fatty acid qualitative composition. We have also used cluster analysis while investigating their quantitative com- 
Table

Fatty acids content in Enterococcus strains of different species

\begin{tabular}{|l|c|c|c|c|c|}
\hline \multirow{2}{*}{ Fatty acid } & \multicolumn{5}{|c|}{$\begin{array}{c}\text { species, } \\
\text { fatty acid content, \% }\end{array}$} \\
\cline { 2 - 6 } & $\boldsymbol{E}$. faecium & $\boldsymbol{E}$. durans & $\boldsymbol{E}$. hirae & $\boldsymbol{E}$. faecalis & Enterococcus sp \\
\hline C14:0 & $2.3 \pm 0.24$ & $2.29 \pm 0.49$ & $1.88 \pm 0.33$ & $2.77 \pm 1.36$ & $3.27 \pm 1.13$ \\
\hline C15:0 & $0.28 \pm 0.07$ & $0.17 \pm 0.08$ & $0.36 \pm 0.18$ & 0 & $0.23 \pm 0.23$ \\
\hline C16:0 & $32.07 \pm 1.54$ & $31.44 \pm 1.71$ & $33.07 \pm 1.53$ & $22.56 \pm 0.66$ & $32.53 \pm 1.05$ \\
\hline C16:1 & $1.69 \pm 0.28$ & $1.51 \pm 0.42$ & $2.06 \pm 0.56$ & $2.31 \pm 1.38$ & $2.08 \pm 1.19$ \\
\hline C18:0 & $2.59 \pm 0.17$ & $2.74 \pm 0.34$ & $2.76 \pm 0.21$ & $2.08 \pm 0.61$ & $2.40 \pm 0.30$ \\
\hline cC18:1 & $15.39 \pm 1.27$ & $15.97 \pm 1.42$ & $14.61 \pm 1.09$ & $28.12 \pm 6.24$ & $14.11 \pm 1.53$ \\
\hline TC18:1 & $1.14 \pm 0.19$ & $1.28 \pm 0.21$ & $1.54 \pm 0.43$ & $3.4 \pm 0.37$ & $1.52 \pm 0.16$ \\
\hline C19:0cyclo & $38.49 \pm 0.82$ & $37.29 \pm 2.87$ & $39.52 \pm 0.83$ & $26.98 \pm 6.49$ & $37.65 \pm 1.14$ \\
\hline
\end{tabular}

position. However, despite certain difference in fatty acids composition of various strains of Enterococcus species, it was not possible to differentiate them. Based on the data obtained it follows that cellular lipids' fatty acids profile is not differentiating characteristic of closely related species of enterococci [9].

Wide use of molecular genetic methods allowed coping with major deficiencies of phenotypic and chemotaxonomic identification when identifying taxonomic position of closely related species. Thus, while we have identified Lactobacillus plantarum species based on phenotypic properties [39], E. faecium, E. durans, E. hirae, E. faecalis [14], B. infantis, B. breve, $B$. animalis, $B$. dentium $[23,42]$, the molecular typing of LAB and bifidobacteria genera using various types of DNA markers with polymerase chain reaction (PCR) has shown high level of nucleotide sequence variability in the mentioned species of microorganisms. Mini- and microsatellite replication markers usage allowed identifying genome's optional portion variability. High level of variability of DNA sequence of the strains B. longum and L. plantarum, $90 \%$ and $94 \%$, respectively, has been noted [42].

High level nucleotide sequence heterogeneity among L. plantarum strains is declarative of broad adaptability of this type to various conditions of living environment. PCR performed for enterococci with species-specific primers has confirmed phenotypic identification of species E. hirae, E. faecium and E. durans [14].

Re-identification of all of the collected strains has been done with PCR using species-specific primers, primers to nucleotide repeats. As a result of amplification 50 strains of lactic acid bacteria have been re-identified and identified being isolated from various ecological niches - alimentary tract of humans, and warm-blooded and cold-blooded animals, dairy and plant origin foods. These strains refer to L. plantarum, L. acidophilus, L. fermentum, L. delbrueckii, L. casei species.

We've investigated intraspecific heterogeneity of bifidobacteria strains collection isolated from distal portion of intestinal tract of people of various age groups. The strains belong to B. longum, B. dentium, B. bifidum, $B$. animalis subsp. lactis species. The mentioned species of bifidobacteria strains manifested high level of intraspecific cellular polymorphism [42]. In the meantime bifidobacteria have shown much higher degree of intraspecies variability than the three type's of lactic acid bacteria L. plantarum, L. acidophilus, L. fermentum. 
Based on the conducted experiments oligonucleotide primers database was created for the purpose of LAB and bifidobacteria identification.

Biological properties and biosynthetic activity of industry-promising lactic acid bacteria and bifidobacteria

Major natural functions of LAB and bifidobacteria involve high biological activity, macroorganism protection from adverse effects of environmental factors, immune system stimulation. These properties have been taken as a basis for creation of probiotics and functional food using probiotics [3, 29].

One of the major features in LAB's properties is their acid tolerance. It allowed investigating these microorganisms' ability to survive in stomach conditions at low $\mathrm{pH}$ values of gastric juice. Hydrochloric acid and digestive enzymes are the most aggressive agents of gastric juice in regard to microorganisms. Of all those lactic acid bacteria subject to our research following 2 hours exposure to gastric juice $42 \%$ of strains survived and $58 \%$ were completely inhibited [40]. All bifidobacteria strains subject to the research tended to be sensitive to gastric juice effect. Data obtained confirm the data available from the literature testifying negative effect of acid environment on bifidobacteria viability and acid conditions tolerance most of the members of Lactobacillus genus.

An equally important issue related to the LAB and bifidobacteria biological properties is to the investigation of their ability to survive in bile presence. Literature data testify that bacteria being components of probiotics shall be tolerant to various concentrations of bile acids $[6,43]$. These concentrations are within $0.15-0.30 \%$ of bile range. Firstly, we've investigated bacterial viability under $0.3 \%$ bile presence, and then its inhibiting concentration for each strain has been identified. Bile acids effect was species dependent. For instance, L. paracasei strains grew with $0.2 \%$ bile in culture medium, L. acidophilus - with $0.15 \%$, and L. delbrueckii subsp. bulgaricus manifested weak growth with $0.1 \%$ bile [22]. At the same time, L. plantarum strains tolerated bile acids in the best way: they grew in the medium containing $0.3 \%$ bile acids [40].

As for bifidobacteria, their viability at bile acids presence depends both on the isolation source and on the strain. Strains isolated from children manifested the highest sensitivity to bile. Only 10 of 15 strains grew at $0.1 \%$ bile concentration, and no growth was observed with higher concentrations. However, the strains received from mid-aged and elder people showed dynamic growth with $2 \%$ bile concentration in the medium, except $B$. dentium. Strains showed weak growth with $0.3 \%$ bile in the medium. At the same time $B$. animalis was the most tolerant to $0.3 \%$ bile [22].

According to the literature data [6], bile acids tolerance is primarily observed with bacteria isolated from mammals' alimentary tract, but can also be manifested by strains isolated from other sources, in particular from dairy products $[6,40]$. This is due to the fact that bile acids presence in habitat is natural for LAB strains isolated from mammals' alimentary tract.

Adhesive properties of LAB and bifidobacteria are the criterion for their selection as probiotic cultures, providing their efficiency when used as components of biopharmaceuticals [24]. In the aftermath of the research it became apparent that all of the studied bifidobacteria strains are able to adhere to human buccal epithelial cells, while the adhesiveness index varied within a wide range from от 1.76 to 48.1 . Adhesive activity depended neither on bifidobacteria species relation, nor on the isolation source, but was strain specific. B. animalis 
subsp lactis 99 (IAM 48.1), B. longum 144 (IAM 34.7), B. bifidum 278 (IAM 28.7), B. bifidum 345 (IAM 27.31) and B. catenulatum 460 (IAM 27.34) strains were the ones with the highest adhesive properties. B. longum 62A (IAM 3.30), strain 145 (IAM 2.93) and strain 143 (IAM 1.76) had weak adhesive activity. Five of the studied $B$. dentium strains had not manifested high adhesive properties - oral cavity microbiota representatives, causing dental caries. Possibly, it is associated with their localization directly inside tooth caries and does not expand on the whole oral cavity.

All studied strains of lactobacilli have also manifested adhesive properties. However, their adhesive activity in human buccal epithelial cells was much weaker; it did not depend on the isolation source and was of strain-specific character. It was shown that all 26 strains of $L$. plantarum subject to the study adhered to human buccal epithelial cells at various degrees. Low adhesiveness index was manifested by $50 \%$ strains (IAM from 3.63 to 9.95 ), average by $37 \%$ strains (IAM from 10.2 to 14.58). High adhesiveness (IAM from 17.97 to 30.11$)$ was manifested by three $(12.5 \%)$ strains only [40]. Ability to adhere to epithelium cells causes LAB survival in various habitats within a macroorganism and possibility to create biofilms thus performing passive antagonism to pathogenic flora. Also, the lactic acid bacteria adhesion to specific biotope's epithelium surface allows them to perform continuous monitoring of nutrients content in the habitat, and reproduce forming protective monolayers creating barriers for pathogen penetration [27].

Microbial cell surface layer components, in particular teichoic acids, are actively involved in the process of adhesion. Teichoic acids participation in this process facilitates the manifestation probiotic functions. Teichoic acids structure is highly strain-specific, and these functions' manifestation depends on their specific features [27].

To evaluate the role of teichoic acids in adhesion of the studied LAB strains from which these acids were isolated, we've treated the targeted epithelium cells. It was found that LAB's teichoic acids preliminary contact with buccal cells causes a decrease of the mean values of adhesion. Moreover, L. plantarum teichoic acid preparation decreased the adhesiveness index of the given strain for $29.1 \%$. Likewise the number of buccal cells involved in adhesive process also decreased along with the percentage of cells with a big number of adhered bacteria. It suggests that teichoic acids prevent the adhesion of lactobacilli strains from which they were isolated [26].

An important issue in this context is to identify the mechanisms of manifestation of probiotic properties by lactic acid bacteria. This process can incorporate the aspects which are of major importance for probiotic properties, such as cell surface hydrophobic behavior, sensitivity to antibiotics and autolytic activity [30]. Bacteria cell surface hydrophobic behavior means its adhesiveness to the epithelial cells and is probiotic strains viability factor in the conditions of various macroorganism biotopes. Hydrophobic behavior properties are related to the degree of cell wall polarity and its charge and depend on its components' properties $[11,28]$. In this regard it seemed relevant to study the relationship between the phosphates content (phosphorus containing teichoic acids) in the medium and the degree of microbial cell hydrophobicity. Solvent agents of various donor-acceptor properties and polarity were used for the study. The study of hydrophobic behavior of L. plantarum strains identified differences 
between strains under cells treatment with chloroform, hexane, ethyl acetate. Under L. plantarum 11/16 strain treatment with chloroform, the hydrophobic value was $25.8 \%$, and L. plantarum 195D strain $-53.9 \%$; and with hexane treatment $-23.6 \%$ for $11 / 16$ strain and $38.2 \%$ for $195 \mathrm{D}$ strain.

Analysis of hydrophobic properties of lactobacilli cells in conditions with various content of inorganic phosphates as one of the major components required for teichoic acids synthesis has shown that inorganic phosphorus content in culture medium effected lactobacilli cell hydrophobic properties along with the solvent agent: chloroform and hexane reduced the hydrophobic value to $11-15 \%$, and inorganic phosphate absence in the medium increased the hydrophobic value up to $64.8 \%$ [28].

Biofilm formation by LAB strains provides their viability in adverse conditions of macroorganism's alimentary tract. We've studies the ability to create biofilm by 24 strains of $L$. plantarum, isolated from various fermented foods. Of all the strains subject to the research $3.7 \%$ manifested high ability for biofilm creation. $79 \%$ of strains were characterized by an average ration of its biofilm formation and only one strain of all the studied ones was practically incapable of creating a film. Biofilm creation process did not depend on strain isolation source. However, it is worth mentioning that two strains of L. plantarum, featured with the highest coefficient of biofilm formation, were isolated from the curd cheese [40].

Lactic acid bacteria sensitivity to antibiotics effect is one of the manifestations of its probiotic properties. As probiotic agents are often used on an antibiotic treatment background, it was useful to study the sensitivity to antibiotics of lactobacilli, enterococci and bifidobacteria monocultures subject to the study. We've established that bifidobacteria strains manifested sensitivity to all inhibitors of cell wall synthesis, except ceftibuten, to which $B$. animalis was resistant [33]. Lactobacilli have also manifested sensitivity to the majority of this range of antibiotics, however, L. paracase $i$ was resistant to vancomycin and ceftibuten, L. delbrueckii subsp bulgaricus tolerates ceftazidime. Moreover, all lactobacilli strains showed resistance to cefepime [22].

Antibiotics inhibiting protein synthesis exhibit various action on the cultures subject to study. L. plantarum strains were resistant to aminoglycosides and fluoroquinolones, which is caused by the absence of an action target of these antibiotics in lactobacilli. Besides that, lactobacilli antibiotic sensitivity was of strain-specific nature and did not depend on its isolation source [40]. Bifidobacteria were also resistant to aminoglycosides action, which is caused by their anaerobic metabolic pattern [17]. Nitrofuran preparations exhibited various effects both on lactobacilli and on bifidobacteria. All strains of B. aimalis, L. paracasei, L. acidophilus and L. delbrueckii subsp bulgaricus were resistant to fusidin [22].

Nucleic acids transcription and synthesis inhibitors also exhibited various effects on the strains subject to investigation. They were sensitive to rifampicin and ofloxacin. L. acidophilus, L. delbrueckii subsp. bulgaricus, B. animalis strains were resistant to lomefloxacin and norfloxacin, L. paracasei manifested intermediate sensitivity to lomefloxacin [22].

Data received as a result of studying 58 strains of enterococci isolated from long-livers are to be referred to important research of antibiotic susceptibility. $9 \%$ of the strains subject to the study were not resistant to clinically-significant 
antibiotics, $12 \%$ of strains manifested intermediate susceptibility and $79 \%$ of strains were resistant to clinically-significant antibiotics [13].

Therefore, identification of the taxonomic position of lactobacilli, enterococci and bifidobacteria isolated from various ecological niches in compliance with modern taxonomy has shown that the isolated strains refer to L. plantarum, E. faecium, E. durans, E. hirae, E. faecalis species. Bifidobacteria were mainly represented by $B$. infantis, $B$. breve, $B$. animalis, $B$. bifidum and B. dentium species.

Enterococcus spp. cellular lipids' fatty acid analysis did not allow to identify clearly the systematic position of closely related species.

$\mathrm{LAB}$ and bifidobacteria genome molecular typing with various types of DNA markers using PCR has identified high level of nucleotide sequence variability within this genus of microorganisms.

All strains subject to this researh have manifested different biological activity: gastric juice resistance, tolerance to various concentrations of bile acids, adhesive properties to macroorganism's epithelial cells, and participation of performance and teichoic acids in this process, sensitivity to clinically significant antibiotics. All these properties make specific strains to be promising for probiotics and functional foods creation.

\section{В.С. Підгорський, Н.К. Коваленко, І.Л. Гармашева}

Інститут мікробіології і вірусологї̈ ім. Д.К. Заболотного НАН України, вул. Академіка Заболотного, 154, Київ, 03143, Украӥна

\section{ТАКСОНОМІЧНІ ДОСЛІДЖЕННЯ, БІОЛОГІЧНІ ВЛАСТИВОСТІ Й БІОСИНТЕТИЧНА АКТИВНІСТЬ МОЛОЧНОКИСЛИХ БАКТЕРІЙ I БІФІДОБАКТЕРІЙ, ІЗОЛЬОВАНИХ 3 РІЗНИХ ПРИРОДНИХ ЕКОНІШ}

Резюме

Молочнокислі бактерії (МКБ) і біфідобактерії відіграють важливу роль у здоров’ї людини та мають широке практичне застосування в харчовій промисловості. Розповсюдження молочнокислих бактерій та їх висока чисельність у природних субстратах свідчать про те, що багато видів цих мікроорганізмів адаптувались до умов оточуючого середовища та окремих еконіш. Молочнокислі бактерії, ізольовані з різних екологічних ніш, були ідентифіковані з використанням фенотипових і молекулярногенетичних методів. Серед МКБ, в основному, були ідентифіковані види Lactobacillus plantarum, Enterococcus faecium, E. durans, E. hirae, E. faecalis. Біфідобактерії були в основному представлені видами Bifidobacterium infantis, B. breve, B. animalis, B. bifidum i $B$. dentium. Була вивчена внутрішньовидова гетерогенність штамів МКБ і біфідобактерій, ізольованих з дистального відділу кишкового тракту людей різних вікових груп. Оцінена роль тейхоєвих кислот в адгезії штамів МКБ до букального епітелію людини. Вивчені різні біологічні активності, такі як стійкість до шлункового соку, стійкість до жовчних кислот, адгезивні властивості до епітеліальних клітин макроорганізму, чутливість до клінічно важливих антибіотиків. Всі ці властивості роблять окремі штами МКБ і біфідобактерій перспективними для створення пробіотичних препаратів і продуктів функціонального харчування.

Ключові слова: молочнокислі бактерії, біфідобактерії, пробіотичні властивості, таксономія. 


\section{В.С. Подгорский, Н.К. Коваленко, И.Л. Гармашева}

Институт микробиологии и вирусологии им. Д.К. Заболотного НАН Украины,, ул. Академика Заболотного, 154, Киев, 03143, Украина

\section{ТАКСОНОМИЧЕСКИЕ ИССЛЕДОВАНИЯ, БИОЛОГИЧЕСКИЕ СВОЙСТВА И БИОСИНТЕТИЧЕСКАЯ АКТИВНОСТЬ МОЛОЧНОКИСЛЫХ БАКТЕРИЙ И БИФИДОБАКТЕРИЙ, ВЫДЕЛЕННЫХ ИЗ РАЗЛИЧНЫХ ПРИРОДНЫХ ЭКОНИШ}

Резюме

Молочнокислые бактерии (МКБ) и бифидобактерии играют важную роль в здоровье человека и имеют широкое практическое применение в пищевой промышленности. Распространение молочнокислых бактерий и их высокая численность в природных субстратах свидетельствуют о том, что многие виды этих микроорганизмов адаптировались к окружающим условиям и отдельным эконишам. Молочнокислые бактерии, изолированные из различных экологических ниш, были идентифицированы с использованием фенотипических и молекулярно-генетических методов. Среди МКБ, в основном, были идентифицированы виды Lactobacillus plantarum, Enterococcus faecium, E. durans, E. hirae, E. faecalis. Бифидобактерии были в основном представлены видами Bifidobacterium infantis, B. breve, B. animalis, B. bifidum и $B$. dentium. Была изучена внутривидовая гетерогенность штаммов МКБ и бифидобактерий, выделенных из дистального отдела кишечного тракта людей разных возрастных групп. Оценена роль тейхоевых кислот в адгезии штаммов МКБ к буккальному эпителию человека. Изучены различные биологические активности, такие как устойчивость к желудочному соку, устойчивость к желчным кислотам, адгезивные свойства к эпителиальным клеткам макроорганизма, чувствительность к клинически важным антибиотиками. Все эти свойства делают отдельные штаммы МКБ и бифидобактерий перспективными для создания пробиотических препаратов и продуктов функционального питания.

Ключевые слова: молочнокислые бактерии, бифидобактерии, пробиотические свойства, таксономия.

1. Alves PI, Martins MP, Semedo T. Figueiredo Marques JJ, Tenreiro R, Barreto Crespo $M T$. Comparison of phenotypic and genotypic taxonomic methods for the identification of dairy enterococci. Antonie van Leeuwenhoek. 2004; 85(3): 237-252.

2. Angeletti S, Lorino G, Gherardi G, Battistoni F, De Cesaris M, Dicuonzo G. Routine molecular identification of enterococci by gene-specific PCR and 16S ribosomal DNA sequencing. J Clin Microbiol. 2001; 39(2): 794-797.

3. Bäckhed F, Ley RE, Sonnenburg JL, Peterson DA, Gordon JI. Host-bacterial mutualism in the human intestine. Science. 2005; 307(5717): 1915-1920.

4. Biavatti B, Vescovo M, Torriani S, Botazzi V. Bifidobacteria: ecology, physiology and application. Ann Microbiol. 2000; 50(1): 117-131.

5. Bosley GS, Wallace PL, Moss CW, Steigerwalt AG, Brenner DJ, Swenson JM et al. Phenotypic characterization, cellular fatty acid composition and DNA relatedness of Aerococci and comparison to related species. J Clin Microbiol. 1990; 28(3): 416-423.

6. Chou LS, Weimer B. Isolation and characterization of acid- and bile-tolerant isolates from strains of Lactobacillus plantarum. J Dairy Sci. 1999; 82: 23-31.

7. Fortina MG, Ricci G, Mora D, Manachini PL. Molecular analysis of artisanal cheeses 
reveals Enterococcus italicus sp. nov. Int J Syst Evol Microbiol. 2004; 54(5): 17171721.

8. Franzetti L, Pompei M, Scarpellini M, Galli A. Phenotypic and genotypic characterization of Enterococcus spp. of different origins. Curr Microbiol. 2004; 49(4): 255-260.

9. Garmasheva IL, Kovalenko NK. [Identification and taxonomy of Enterococci]. Mikrobiol Z. 2010; 72(5): 49-58. Russian.

10. Garcia Fontan MC, Franco I, Tornadijo ME, Carballo J. Identification of enterococci isolated from cow's milk cheese: comparison of the classical methods and the API 20 STREP system (technical note). Acta Microbiol Immunol Hung. 2002; 49(1): 119-128.

11. Giaouris E, Chapot-Chartier MP, Briandet R. Surface physicochemical analysis of natural Lactococcus lactis strains reveals the existence of hydrophobic and low charged strains with altered adhesive properties. Int J Food Microbiol. 2009; 131(1): 2-9.

12. Gibson GR, Rastall RA. Gastrointestinal infection infection and the protective role of probiotics and prebiotics. Food Sci Technol Bull. 2003; 1: 35-52.

13. Harmasheva IL, Kovalenko NK. [Antibiotic resistance in enterococci isolated from gastrointestinal tract of long-livers]. Mikrobiol Z. 2008; 70(1): 45-51. Ukrainian.

14. Harmasheva IL, Kovalenko NK, Zelena LB. [Identification of Enterococci strains]. Mikrobiol Z. 2009; 71(2): 3-12. Ukrainian.

15. Harwood VJ, Delahoua NC, Ulrich RM, Kramer MF, Whitlock JE, Garey JR. Molecular conformation of Enterococcus faecalis and Enterococcus faecium from clinical, faecal and environmental sources. Lett Appl Microbiol. 2004; 38(6): 476-482.

16. Hudson CR, Fedorka-Cray PJ, Jackson-Hall MC, Hiott LM. Anomalies in species identification of enterococci from veterinary sources using a commercial biochemical identification system. Lett Appl Microbiol. 2003; 36(4): 245-250.

17. Jaana M, Angela H, Konrad J. Susceptibility of human and probiotic Bifidobacterium spp. to selected antibiotics as determined by the E-test method. Int Dairy J. 2007; 17: $1123-1131$.

18. Jackson CR, Fedorka-Cray PJ, Barrett JB. Use of a genus- and species-specific multiplex PCR for identification of enterococci. J Clin Microbiol. 2004; 42(8): 3558 3565.

19. Kang KH, Shin HJ, Parc YH, Lee TS. Studies on the antibacterial substances produced by lactic acid bacteria: purification and some properties of antibacterial substance "Bifilong" produced by B. longum. Kor Dairy Sci. 1989; 1: 204-216.

20. Knudston LM, Hartman PA. Routine procedures for isolation and identification of enterococci and fecal streptococci. Appl Environ Microbiol. 1992; 58(9): 3027-3031.

21. Kovalenko NK, Kasumova SA, Muchnik FV. [Screening of the strains of lactic acid bacteria possessing hypocholesterinemic activity and their practical use]. Mikrobiol Z. 2004; 66(3): 33-42. Russian.

22. Kovalenko NK, Livins'ka OP, Poltavs'ka OA, Harmasheva IL, Shynkarenko LM, Oleshchenko LT. [Probiotic properties of industrial strains of lactobacilli and bifidobacteria]. Mikrobiol Z. 2010; 72(1): 9-17. Ukrainian.

23. Kovalenko NK, Poltavskaia OA, Zelenaia LB. [Bifidobacterial species composition of digestive tract of people of different age groups]. Mikrobiol Z. 2012; 74(1): 8-13. Russian. 
24. Liaskovskil TM, Podgorskiŭ VS. [Assessment of probiotics according to the international organizations (FAO/WHO)]. Mikrobiol Z. 2005; 67(6): 104-12. Russian.

25. Liaskovs'kyı̌ TM, Pidhors'ky̌ VS, Kovalenko NK, Harmasheva IL, Muchnyk FV. [Identification of probiotic lactic acid bacteria strains]. Mikrobiol Z. 2008; 70(6): 3-9. Ukrainian.

26. Livins'ka OP, Garmasheva IL, Kovalenko NK. [The influence of teichoic acids from probiotic lactobacilli on microbial adhesion to epithelial cells]. Mikrobiol Z. 2012; 74(3): 16-22. Ukrainian.

27. Livins'ka OP, Harmasheva IL, Kovalenko NK. [Teichoic acids from lactic acid bacteria]. Mikrobiol Z. 2012; 74(4): 87-94. Ukrainian.

28. Livins'ka OP, Harmasheva IL, Kovalenko NK. [Effect of inorganic phosphate on the properties of Lactobacilli probiotic strains]. Mikrobiol Z. 2014; 76(2): 10-16. Ukrainian.

29. Marco ML, Pavan S, Kleerebezem M. Towards understanding molecular modes of probiotic action. Curr Opin Biotechnol. 2006; 17: 204-210.

30. Naumova IB, Shashkov AS, Tul'skaya EM, Streshinskaya GM, Kozlova YI, Potekhina $N V$, et al. Cell wall teichoic acids: structural diversity, species specificity in the genus Nocardiopsis, and chemotaxonomic perspective. FEMS Microbiol Rev. 2001; 25(3): 269-84.

31. Ohirchuk KS, Kovalenko NK, Poltavs'ka OA. [Identification and biological properties of intestinal lactic acid bacteria isolated from aged women]. Mikrobiol Z. 2013; 75(5): 3-9. Ukrainian.

32. Peretz PF, Minnaard J, Disalvo EA, Antoni GL. Surface properties of bifidobacterial strains of human origin. Appl Environ Microbiol. 2014; 64(1): 21-26.

33. Poltavs'ka OA, Kovalenko NK. [Antibiotic sensitivity of bifidobacteria isolated from different natural sources]. Mikrobiol Z. 2005; 67(6): 32-9. Ukrainian.

34. Pompei R, Berlutti F, Thaller MC, Ingianni A, Cortis G, Dainelli B. Enterococcus flavescens sp. nov., a new species of enterococci of clinical origin. Int J Syst Bacteriol. 1992; 42(3): 365-369.

35. Sedov VI, Pinchuk LM. [Higher fatty acid composition of enterococci]. Zh Mikrobiol Epidemiol Immunobiol. 1982; (9): 49-53. Russian.

36. Sukontasing S, Tanasupawat S, Moonmangmee S, Lee JS, Suzuki K. Enterococcus camelliae sp. nov., isolated from fermented tea leaves in Thailand. Int J Syst Evol Microbiol. 2007; 57(9): 2151-2154.

37. Tanasupawat S, Sukontasing S, Lee JS. Enterococcus thailandicus sp. nov., isolated from fermented sausage ('mum') in Thailand. Int J Syst Evol Microbiol. 2008; 58(7): $1630-1634$.

38. Tyrrell GJ, Turnbull L, Teixeira LM, Lefebvre J, Carvalho Mda G, Facklam RR et al. Enterococcus gilvus sp. nov. and Enterococcus pallens sp. nov. isolated from human clinical specimens. J Clin Microbiol. 2002; 40(4): 1140-1145.

39. Vasyliuk OM, Kovalenko NK, Harmasheva IL, Oleshchenko LT. [Isolation and identification of bacteria of Lactobacillus genus from fermented products in different regions of Ukraine]. Mikrobiol Z. 2014; 76(2): 2-9. Ukrainian.

40. Vasyliuk OM, Garmasheva IL, Kovalenko NK. Probiotic properties of strains Lactobacillus plantarum isolated from fermented products. Microbiol Biotechnol. 2014; 27(3): $23-30$. 
41. Velasco D, Perez S, Peña F, Dominguez MA, Cartelle M, Molina F, et al. Lack of correlation between phenotypic techniques and PCR-based genotypic methods for identification of Enterococcus spp. Diagn Microb Infect Dis. 2004; 49(3): 151-156.

42. Zelena LB, Kovalenko NK, Poltavska OA. [Intraspecies variability of bifidobacteria colonizing human gastro-intestinal tract]. Mikrobiol Z. 2011; 73(3): 9-13. Ukrainian.

43. Yazid W, Shuhaimi M, Ghazali M. Survival of bifidobacteria in simulated gastric $\mathrm{pH}$ and growth in the presence of bile. Asia J Mol Biol Biotechnol. 1999; 7(2): 185-188.

Отримано 07.09.2016 